\title{
STUDY OF THE DISTRIBUTION PATTERN OF SCHISTOSOMA HAEMATOBIUM EGG ANTIGENS RECOGNISED BY SIX DIFFERENT MONOCLONAL ANTIBODIES IN THE PARASITE AND THE HOST
}

\author{
ROYERS R*, JACOBS W*§, BOGERS J.J.*, DEELDER A.M..* \& VAN MARCK E.*
}

\begin{abstract}
Summary :
Recently a new panel of monoclonal antibodies was developed against soluble egg antigens in the hatching fluid of Schistosoma mansoni. These antibodies have been used to develop an improved ELISA for the detection of circulating soluble egg antigens in serum and urine that would have a higher sensitivity in the immunodiagnosis of $S$. mansoni infections. Although these antibodies showed no improvement in the immunodiagnosis of S. mansoni infections compared with egg antigen-based ELISAs already described (Nourel Din et al., 1994a), they may have a potential role in the identification of $S$. haematobium infections.

This study has looked into the immunolocalisation of

S. haematobium egg antigens in both the parasite and the host as recognised by four newly developed monoclonal antibodies (2902D9-A, 290-2E6-A, 290-2H12-A and 290-4A8-A) and two already described antibodies (1 14-5B 1-A and 114-4D 12-A). The antibodies 114-5B 1-A and 1 14-4D12-A appeared to have in S. haematobium eggs a similar staining pattern when compared to $S$. mansoni eggs. The antibodies prepared against the hatching fluid showed a characteristic signal, especially 290-2E6-A. These antibodies recognised a component originating from the lateral glands of the miracidium. In the host a similar immunohistochemical tissue localisation pattern (mainly phagocytising reticulo-endothelial cells) was seen as previously described for S. mansoni infected hamsters.
\end{abstract}

KEY WORDS : Schistosoma haematobium, egg antigen, immunolocalisation, parasite, host, hatching fluid.
Résumé : ÉTUDE IMMUNOHISTOCHIMIQUE DE LA DISTRIBUTION D'ANTIGĖNES D'œUFS DE SCHISTOSOMA HAEMATOBIUM RECONNUS PAR SIX ANTICORPS MONOCLONAUX DIFFÉRENTS DANS LE PARASITE ET L'HÔTE

Récemment, de nouveaux anticorps monoclonaux dirigés contre des antigènes présents dans le liquide d'éclosion de Schistosoma mansoni ont été développés. Ces anticorps ont été employés pour la mise au point d'un test ELISA de haute sensibilité pour la détection d'antigènes solubles et circulants dans le sérum et dans les urines, afin de permettre le diagnostic immunologique d'infections à S. mansoni. Bien que ces anticorps ne montraient pas d'amélioration dans le diagnostic immunologique comparé avec les tests. ELISA à base d'antigènes d'œuts déjà existants (Nourel Din et al., 1994a), ils jouent un rôle potentiel dans l'identification d'infections à S. haematobium. Cette étude a pour but la localisation immunohistochimique d'antigènes d'cuts de S. haematobium, aussi bien dans le parasite que dans l'hôte, antigènes reconnus par quatre anticorps nouveaux (290-2D9-A, 290-2E6-A, 290-2H12-A et 290-4A8-Al et deux anticorps déjà décrits (1 14-5B 1-A et 1 14-4D 12-A). Les anticorps 1 14-5B 1-A et 1 14-4D $12-A$ avaient tendance à montrer un patron dans les œufs de S. haematobium tel qu'il a déjà été décrit pour les œufs de S. mansoni. Les anticorps préparés contre le liquide d'éclosion montraient un signal caractéristique plus particulièrement 290-2E6A. Ces anticorps reconnaissent probablement une composante des glandes latérales du miracidium. Une distribution immunohistochimique tissulaire dans l'hôte /surtout dans des cellules à pouvoir phagocytaire, réticulo-endothéliales), similaire à celle déjà décrite dans des hamsters infectés avec $S$. mansoni a également été observée.

MOTS CLÉS : Schistosoma haematobium, antigène d'œuf, immunolocalisation, parasite, hôte, liquide d'éclosion.

et al., 1980; Nourel Din et al., 1994a). Much research has been focussed on the development of tests for the detection of circulating adult worm antigens in the serum and urine of patients to estimate the worm load in the tissues of the host (Carlier et al., 1980; Deelder et al., 1980). Many eggs excreted by the female worms never reach the exterior, but remain trapped in the tissues, mainly the liver and intestine. The induction of granulomas around the eggs by the host leads to fibrosis of the liver, ureters and urinary bladder and is the main cause of the morbidity (and mortality) in human schistosomiasis. An egg antigen specific test can therefore possibly offer specific information of the egg burden in the infected tissues and can thus possibly be a good parameter for the prediction of pathology (Nourel Din et al., 1994a; Nibbeling et al., 1998; Kahama, 1998b).

\footnotetext{
* Laboratory of Pathology, University of Antwerp (UIA), Wilrijk, Belgium.

** Department of Parasitology, Leiden University Medical Centre, Leiden, The Netherlands.

$s$ Research Assistant of the Fund for Scientific Research-Flanders. Correspondence: Prof. Dr. Eric Van Marck, Department of Pathology, University of Antwerp (UIA), Universiteitsplein 1, B-2610 Wilrijk, Belgium.

Tel.: +32-3-821.36.04 - Fax: +32-3-820.25.32.

E-mail: eric.van marck@uza.uia.ac.be
} 
We earlier described two monoclonal antibodies (1145B1-A and 114-4D12-A) for the specific detection of circulating soluble egg antigens (CSEAs) (Nourel Din et al., 1994a). These assays, however, lacked sensitivity for very light infections compared with egg counts in faeces and CAA and CCA measurements (Nibbeling et al., 1998). Nibbeling et al. (1998) described the production of new antibodies in an attempt to develop assays with an improved sensitivity in the diagnosis of $S$. mansoni infections. None of these antibodies showed an improvement in the immunodiagnosis compared with existing ELISAs, but they may have a potential role in the identification of S. haematobium infections, because it is known that $S$. mansoni and $S$. haematobium have corresponding epitopes on their antigens or even have corresponding antigens (Hamburger et al., 1982; Dunne et al., 1987).

Egg antigens detected in urine would primarily originate from eggs in the urine and eggs entrapped in the bladder wall and secondarily from antigens that pass the glomerulus. This implies that detection of SEA in the urine of Schistosoma infected individuals will be relatively easier in $S$. haematobium infection than in $S$. mansoni infections since the bladder is the primary target organ in the former infection. As the detection levels of antigens are not only function of the amount released by the parasite, but also on how they are processed by the host, it is necessary to study these processes (Bogers et al., 1995b).

The present study was focussed on the immunohistochemical localisation patterns of egg antigens in the host and parasite ( $S$. haematobium) that are recognised by the recently developed monoclonal antibodies 290-2D9-A, 290-2E6-A, 290-2H12-A and 290-4A8$\mathrm{A}$ and also by two monoclonal antibodies already described in S. mansoni infections (114-5B1-A and 114-4D12-A).

\section{MATERIALS AND METHODS}

\section{COLLECTION OF TISSUES AND FIXATION}

$\mathrm{H}$ amsters were experimentally infected with 1,200 cercariae of the NAMRU3 strain (Cairo) of S. haematobium. After 16, 18 or 20 weeks of infection, the hamsters were sacrificed (overdose pentobarbital) and perfused with Dulbecco's solution. The liver, spleen, a part of the ileum and colon were sampled and frozen in liquid nitrogen or fixed in neutral buffered formaldehyde.

\section{PREPARATION OF MONOCLONAL ANTIBODIES}

The monoclonal antibodies 114-5B1-A and 114-4D12A were synthesised as described by Nourel Din et al. (1994a). Briefly, spleen cells of S.mansoni infected BALB/C Swiss mice were fused with SP2/0 mice myeloma cells. The hybridoma cell supernatants were tested by an indirect immunofluorescent assay on S. mansoni worms or liver cryosections of S. mansoni infected hamsters. Cells with the desired specificity were cloned by limiting dilutions producing the 1145B1-A (IgG1) and 114-4D12-A (IgG1) monoclonal antibodies.

The monoclonal anti-egg antibodies 290-2D9-A, 2902E6-A, 290-2H12-A and 290-4A8-A were prepared as described by Nibbeling et al. (1998). BALB/c mice were immunised with S. mansoni hatching fluid (HF). Spleen cells were fused with SP2/0 mouse myeloma cells. Hybridoma cells were selected by an immunofluorescent assay (IFA) on liver cryosections of $S$. mansoni infected hamsters and with a HF-ELISA. Hybridoma supernatants positive in the HF-ELISA and showing a strong reactivity in the IFA with eggs were selected for further studies. Hybridoma cells were cloned and precipitates of the supernatants were tested by immunodiffusion to select for monoclonal antibodies recognising repetitive epitopes. Hybridoma cells were cloned by limiting dilutions and monoclonal antibodies were produced by in vitro production. The antibodies were purified as described by De Jonge et al. (1990). The antibodies used were either in pure form or FITC (fluorescein isothiocyanate) labelled (Kahama et al., 1998a; Kahama, 1998b).

\section{IMMUNOHISTOCHEMISTRY}

A. Immunofluorescent technique: Cryosections $4-5 \mu \mathrm{m}$ thick of the liver, spleen, ileum and colon from $S$. haematobium infected hamsters were cut, air-dried and fixed in cold acetone $\left(20^{\circ} \mathrm{C}, 10\right.$ minutes). The primary (FITC-labelled) monoclonal antibodies were applied in the appropriate dilutions (Table I) and incubated overnight at $4^{\circ} \mathrm{C}$ in a humid room. Finally, the sections were rinsed with demineralised water and covered with Vectashield (Vector Laboratories Inc., Burlingame,

\begin{tabular}{ccccc}
\hline & $\begin{array}{c}\text { Protein } \\
\text { concentration } \\
(\mathbf{m g} / \mathbf{m l}) \\
\text { Fluorescence } \\
\text { technique }\end{array}$ & Dilution & $\begin{array}{c}\text { Protein } \\
\text { concentration } \\
\text { (mg/ml) } \\
\text { Immuno- } \\
\text { peroxidase } \\
\text { technique }\end{array}$ & Dilution \\
\hline 114-5B1-A & 2.6 & $1 / 100$ & 1,2 & $1 / 50$ \\
$114-4 \mathrm{D} 12-\mathrm{A}$ & 2.6 & $1 / 100$ & 1,1 & $1 / 50$ \\
$290-2 \mathrm{D} 9-\mathrm{A}$ & 6.95 & $1 / 80$ & 1,6 & $1 / 20$ \\
$290-2 \mathrm{E} 6-\mathrm{A}$ & 1.9 & $1 / 80$ & 0,4 & $1 / 20$ \\
$290-2 \mathrm{H} 12-\mathrm{A}$ & 8.45 & $1 / 80$ & 1,3 & $1 / 30$ \\
$290-4 \mathrm{~A} 8-\mathrm{A}$ & 3.8 & $1 / 80$ & 1,2 & $1 / 30$ \\
\hline
\end{tabular}

Table I. - Antibodies used for immunohistochemistry and dilutions applied. 
USA). FITC-labelled sections were examined on a Zeiss LSM 410 confocal laser scanning microscope (Zeiss, Oberkochen, Germany) equipped with an argon laser (488 nm).

B. Indirect immunoperoxidase staining technique: Cryosections $4-5 \mu \mathrm{m}$ thick of the liver, spleen, ileum and colon from $S$. haematobium infected hamsters were cut, air-dried and fixed in cold acetone. Endogenous peroxidase activity was blocked by incubating the sections in $50 \mathrm{ml}$ ethanol with $0.5 \mathrm{ml}$ hydrogen peroxide (30\%). The sections were then incubated (30 minutes) with blocking buffer $20 \%$ normal goat serum (Jackson ImmunoResearch Laboratories Inc., West Grove, USA) $+5 \%$ milk powder dissolved in TBS] to inhibit nonspecific binding. The primary monoclonal antibodies were used in appropriate dilutions [TBS $+5 \%$ milk powder $+10 \%$ normal hamster serum (Jackson ImmunoResearch Laboratories Inc.)] (Table I) and incubated overnight at $4^{\circ} \mathrm{C}$ in a humid room. The sections were then incubated for 30 minutes at room temperature with a peroxidase-conjugated secondary antibody (Rockland, Gilbertsville, USA). The colour reaction was developed by incubation with 3-3' diaminobenzidine tetrahydrochloride (DAB, 10 minutes) (Dako, Glostrup, Denmark). The sections were dehydrated, counterstained with Carazzi's haematoxyline and mounted in DPX (FLUKA Chemika-Biochemika, Buchs, Switzerland).

\section{RESULTS}

\section{IMMUNOFLUORESCENT HISTOCHEMISTRY}

W ith the FITC immunofluorescent technique, a striking difference between 114-5B1-A and 114-4D12-A and 290-2D9-A, 290-2E6-A, 2902H12-A, 290-4A8-A was seen. 114-5B1-A and 114-4D12A gave an immunofluorescent pattern that reacted with structural components of the miracidium inside the egg: the frontal and the lateral glands of the miracidium. A double canal system was also visualised, which is the excretory system. In the centre of the miracidium a circle-like structure was seen with 1145B1-A, which were the germinal cells. No immunoreactivity was seen in the liver granulomas when the eggs were intact. If an eggshell was broken up, immunoreactivity could be seen in granuloma cells in the vicinity of the egg, while the rest of the granuloma stained negative.

MABs 290-2D9-A, 290-2E6-A, 290-2H12-A and 290$4 \mathrm{~A} 8-\mathrm{A}$ all gave a similar image, although the signal was strongest for 290-2E6-A. All antibodies showed a pattern with immunoreactivity either in the lateral glands of the miracidium (Fig. 1) or between the miracidium and the eggshell (Fig. 2). With 290-2E6-A, immuno- reactivity was observed around the egg or diffuse staining of the liver granuloma cells in granulomas with intact eggs. This was not seen with the other antibodies.

\section{INDIRECT IMMUNOPEROXIDASE TECHNIQUE}

Immunoreactivity was studied in the liver, spleen, ileum and colon. In liver granulomas there was immunoreactivity in the intact eggs with 114-5B1-A and 114-4D12-A, while the granulomas remained negative. In granulomas with destroyed eggs a slight immunoreactivity was found in the inner peri-ovular cells of the granuloma. Occasional immunoreactive Kupffer cells were seen mainly in close vicinity of the granulomas.

With 290-2D9-A, 290-2E6-A, 290-2H12-A and 290-4A8A immunoreactivity was observed in the eggs. Strikingly, there was, specifically with 290-2E6-A, a strong "diffused out" immunoreactivity signal (Fig. 3). The immunoreactivity was mainly observed in the inner peri-ovular part of the granuloma.

In the spleen there were eggs and granulomas with the same immunohistochemical pattern as described in the liver. All the antibodies showed immunoreactivity in the germinal centre (Fig. 4) of the lymphoid follicles. Sometimes, the periarterial lymphatic sheath (PALS) was stained. The red pulp did not stain.

In the ileum there were focally many granulomas in the submucosa. These granulomas showed a similar image as described in the liver. The epithelium of the villi showed a strong, but incontinous, immunoreactive signal (from the top of the villi to the crypts of Lieberkühn). Occasionally, single immunoreactive cells were seen in the lamina propria, while the muscularis mucosae remained negative. The germinal centres of the Peyer's patches were immunoreactive. The submucosa was entirely non-immunoreactive.

The colon showed a similar image as described in the ileum. Granulomas were present in the mucosa and submucosa, with a slight predisposition for the mucosa. Sporadically immunoreactive cells were seen in the lamina propria.

No changes were seen in the immunoreactivity pattern during ageing infection (16, 18 or 20 weeks postinfection). These results are summarised in Table II.

\section{DISCUSSION}

S ecreted egg antigens are important elements of a schistosome infection both with respect to the diagnosis of the infection as to the pathogenesis of the disease. From a diagnostic point of view, determination of serum and urine levels of secreted egg antigens may provide an estimate of the tissue egg burden 


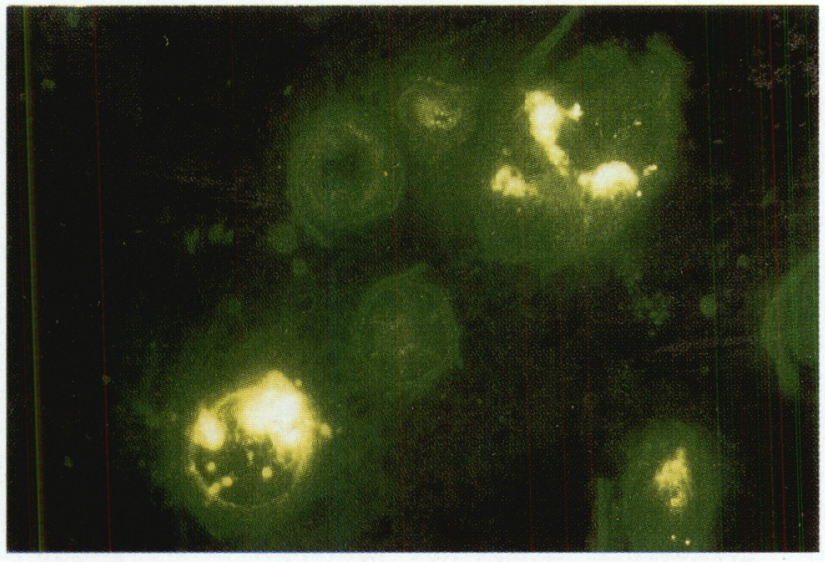

Fig. 1.

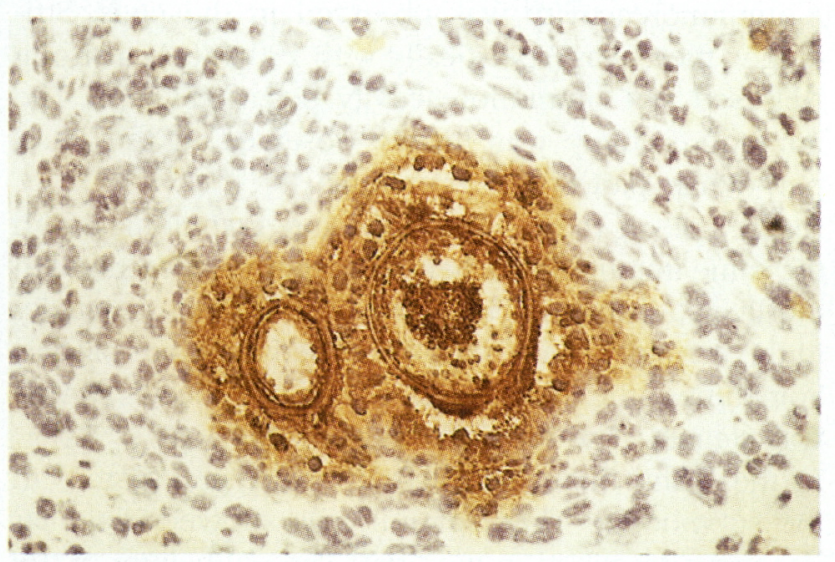

Fig. 3.

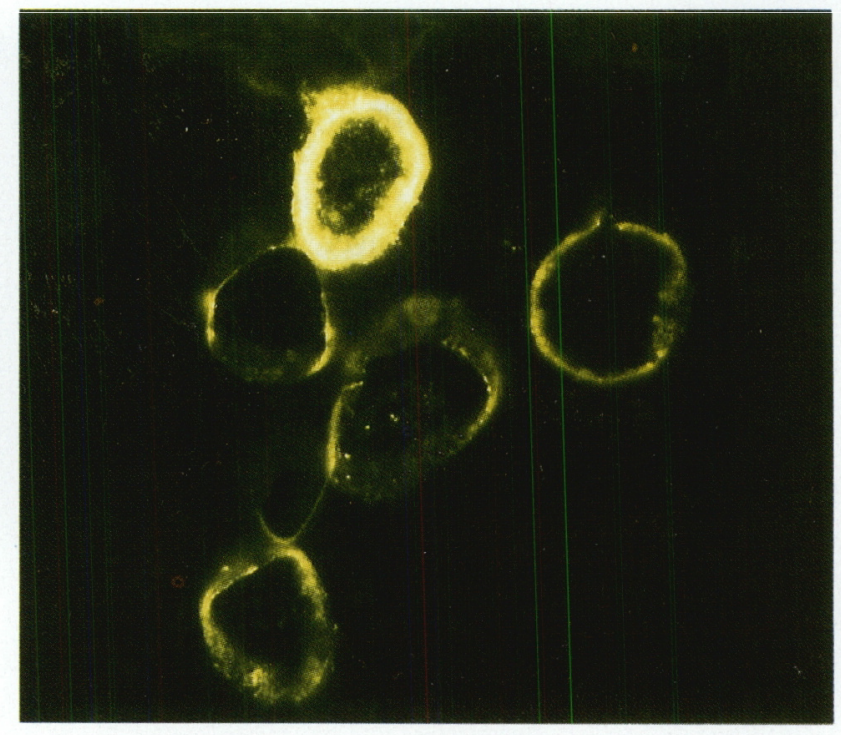

Fig. 2.

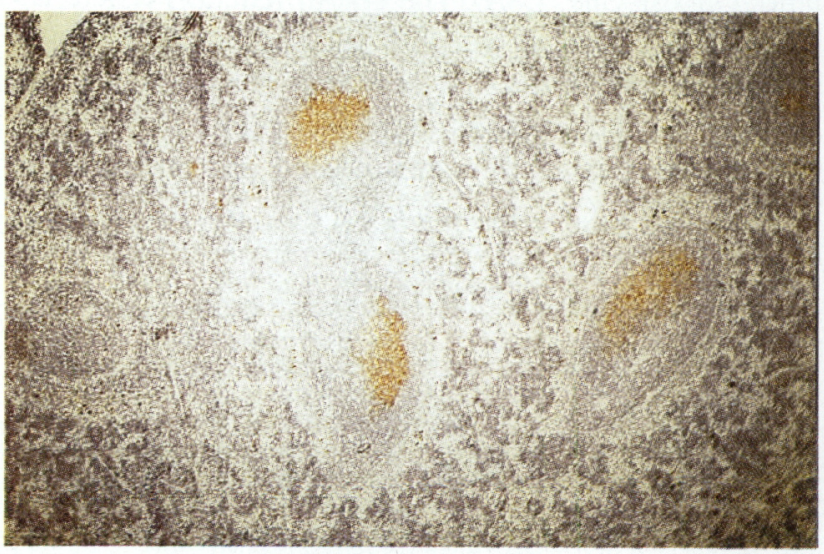

Fig. 4 .

Fig. 1. - Fluorescence image (FITC) of a cluster of Schistosoma haematobium eggs in the liver recognised by the antibody 290-2E6-A (magnification 230x). Immunoreactivity is situated in the lateral glands.

Fig. 2. - Fluorescence image (FITC) of a cluster of Schistosoma haematobium eggs in the liver recognised with antibody 290-2E6-A (magnification 150x). Immunoreactivity is seen in the space between the miracidium and the eggshell.

Fig. 3. - Peri-ovular immunoreactivity (antibody 290-2E6-A) in a submucosal granuloma of the ileum (magnification $290 \times$, immunoperoxidase staining).

Fig. 4. - Immunoreactive germinal centres of lymphoid follicles in the spleen (290-2E6-A) (magnification 15×, immunoperoxidase staining).

Fig.5. - Hypothesis of the fate of Schistosoma haematobium soluble egg antigens in the host's organism.

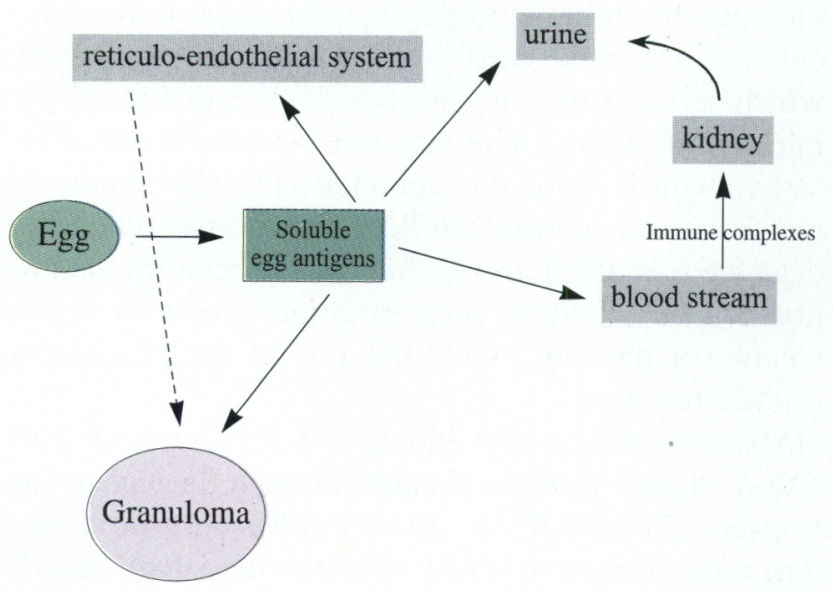

Fig. 5 . 


\begin{tabular}{lll}
\hline Immunofluorescent histochemistry & \multicolumn{1}{c}{ Egg } & \multicolumn{1}{c}{ Granuloma } \\
\hline $\begin{array}{l}\text { 114-5B1-A } \\
114-4 \mathrm{D} 12-\mathrm{A}\end{array}$ & $\begin{array}{l}\text { Frontal and lateral glands } \\
\text { Excretion system } \\
\text { Germinal cells }\end{array}$ & $\begin{array}{l}\text { Peri-ovular cells around } \\
\text { a processed egg (bro- } \\
\text { ken up eggshell) }- \text { re- } \\
\text { maining granuloma cells } \\
\text { non-immunoreactive }\end{array}$ \\
\hline 290-2D9-A & $\begin{array}{l}\text { Lateral glands or between } \\
\text { miracidium and eggshell }\end{array}$ & $\begin{array}{l}\text { Peri-ovular or diffuse } \\
\text { staining of granuloma } \\
\text { (only 290-2E6-A) }\end{array}$ \\
290-2H12-A & $\begin{array}{l}\text { 290-4A8-A } \\
\text { Immunoperoxidase technique (all antibodies tested) }\end{array}$ \\
\hline Liver & $\begin{array}{l}\text { Cells of the granuloma } \\
\text { Kupffer cells }\end{array}$ \\
\hline Spleen & $\begin{array}{l}\text { Cells of the granuloma } \\
\text { Germinal centres and PALS }\end{array}$ \\
\hline Ileum & $\begin{array}{l}\text { Cells of the granuloma } \\
\text { Peyer's patches } \\
\text { Epithelium } \\
\text { Sporadic cells in the lamina propria }\end{array}$ \\
\hline Colon & $\begin{array}{l}\text { Cells of the granuloma } \\
\text { Peyer's patches } \\
\text { Epithelium } \\
\text { Sporadic cells in the lamina propria }\end{array}$ \\
\hline
\end{tabular}

Table II. - Summary of the immunoreactivity patterns for the different antibodies under investigation in both the parasite and the host.

in infected individuals. Tissue-deposited eggs are important from a pathogenic point of view since they secrete large amounts of pro-granulomogenic antigens (Boros, 1989). Nourel Din et al. (1994b) described two antibodies (114-5B1-A and 114-4D12-A) that strongly reacted with repetitive carbohydrate epitopes on soluble $S$. mansoni egg antigens. The tissue distribution of the antigens recognised by these antibodies was next established in both the parasite ( $S$. mansoni) (Bogers et al., 1994, 1995a) and the host (Bogers et al., 1995b). With these antibodies we observed similarities in the reaction pattern in the parasite $S$. haematobium (e.g. lateral and frontal glands of the miracidium), and in the cells of the reticulo-endothelial system of a $S$. haematobium infected host as seen as in S. mansoni. It has been demonstrated that the antibodies 114-5B1-A and 114-4D12-A showed a similar reaction pattern, but that they reacted with different epitopes (Nourel Din et al., 1994b; Bogers et al., 1995a). Since the antibodies 114-5B1-A and 114-4D12-A have similar reaction patterns in both S. haematobium and S. mansoni eggs, this suggests that the same epitopes can be found in both parasites and that probably there exist multiple common antigens on both parasites. This implies that in immunodiagnosis interference can occur resulting in diminished species-specificity (Kahama, 1998b). The developed ELISAs (Nibbeling et al., 1998), demonstra- ting the presence of SEA in the urine, appear however to be a promising method as a diagnostic marker and maybe even as a morbidity marker in $S$. haematobium infections. Significant correlations were found between SEA and egg counts, haematuria, ultrasound detectable pathology, reaction strip index and the levels of the adult worm antigens CAA and CCA (Kahama et al., 1998a).

The presence of the antigens described by Nourel Din et al. (1994b) in the hatching fluid can indicate that these antigens are secreted by the frontal and lateral glands or that they are derived from an excretory system. According to Pan (1980), the unicellular glands have the characteristic of actively secreting cells. Furthermore secreted egg antigens were ultrastructurally found in the apical and lateral glands of $S$. mansoni miracidia (Bogers et al., 1995a). Also in the present study the antibodies detected their corresponding antigens in glandular structures of the miracidium of S. haematobium.

The acquired morphological images with 290-2D9-A, 290-2E6-A, 290-2H12-A and 290-4A8-A demonstrate a kinetic which can be grouped into four phases: 1) glands of the miracidium, 2) between miracidium and eggshell, 3) diffused out of the egg, and 4) in phagocyting cells. This sequence strongly suggests that the egg antigens are secreted by the miracidium, diffuse through the eggshell and are processed by the host. Besides immunoreactivity in Kupffer cells in the liver and possibly in tissue macrophages in the intestinal lamina propria, egg antigens were also processed in the lymphoid aggregates of the spleen, and in the Peyer's patches of the ileum and colon. These observations are in concordance with the work by Bogers et al. (1995b) who observed phagocytised egg antigens in Kupffer cells and splenic macrophages. The observed immunoreactivity in the spleen may be an indication of the importance of this organ in the processing of parasite antigens (Bogers et al., 1995b) and its subsequent ancillary role in the pathogenesis of schistosomiasis (Andrade et al., 1998). In this study, it was also seen that the epithelium of ileum and colon was immunoreactive. Uptake of antigenic substances however can take place in the domes of the gut-associated lymphoid tissue and is achieved by M-cells located in the follicle-associated epithelial lining (Beier \& Gebert, 1998). Upregulation of MHC class II molecules on enterocytes has been observed in inflamed intestines (e.g. Crohn's disease and graft versus host disease) (Koretz et al., 1987; Bland \& Whiting, 1992). The observed egg antigen immunoreactivity detected in enterocytes might thus originate from presented egg antigens (with MHC class II molecules) and coming from eggs excreted in the gut lumen. Furthermore, evidence arises that antigen priming occurs in B-cells in 
the Peyer's patches (Sharma et al., 1998). The importance of the intestine in the immunopathology must be emphasised in view of the fact that in the human body two thirds of the entire immune system is localised in the gut.

It is unclear whether these circulating egg antigens have a (patho)physiological function or that they are merely excreted "by-products". It can be expected that these circulation soluble egg antigen might also have a role in the modulation of the S. haematobium granuloma since it is well established that, in mice, prior sensitisation with egg antigens has profound effects on the outcome of hepatic granulomas after a subsequent challenge S. mansoni infection (Lukacs \& Boros, 1992; Hassanein et al., 1997). The processing by immune cells with an antigen presenting capacity further supports their potential immunological significance. The fate of soluble egg antigens in the host's organism is hypothesised in Figure 5.

From our observation it can be concluded that these newly developed antibodies might be interesting for the detection of $S$. haematobium infections since they clearly recognise $S$. haematobium egg-derived antigens. However, to fully appreciate the significance of detected specific egg-derived antigen levels, an understanding of the production of these antigens by the parasite and the processing of these antigens by the host is mandatory.

\section{REFERENCES}

Andrade Z.A., Silva L.M., De-Souza M.M., Sadigursky M., BarBOSA A. JR. \& DE Oliveira I.R. Role of the spleen on the pathogenesis of schistosomal periportal (pipestem) fibrosis of the liver: an experimental approach. American Journal of Tropical Medicine and Hygiene, 1998, 59, 557-562.

BeIER R. \& GEBERT A. Kinetics of particle uptake in the domes of Peyer's patches. American Journal of Physiology, 1998, $275,130-137$

Bland P.W. \& Whiting C.V. Induction of MHC class II gene products in rat intestinal epithelium during graft-versushost disease and effects on the immune function of the epithelium. Immunology, 1992, 75, 366-371.

Bogers J.J., Nibbeling H.A., Van Marck E. \& Deelder A.M. Immunofluorescent visualisation of the excretory and gut system of Schistosoma mansoni by confocal laser scanning microscopy. American Journal of Tropical Medicine and Hygiene, 1994, 50, 612-619.

Bogers J.J., Nibbeling H.A., Van Marck E. \& Deelder A.M. Immunoelectron microscopical localization of a circulating antigen in the excretory system of Schistosoma mansoni. Parasitology Research, 1995a, 81, 375-381.

Bogers J.J., Nibbeling H.A., Deelder A.M. \& Van Marck E. Immunohistochemical and ultrastructural localization of Schistosoma mansoni soluble egg antigens processed by the infected host. Parasitology, 1995b, 112, 537-543.
Boros D.L. Immunopathology of Schistosoma mansoni infection. Clinical Microbiology Reviews, 1989, 2, 250-269.

Carlier Y., Bout D., Strecker G., Debray H. \& Capron A. Purification, immunochemical, and biologic characterization of the Schistosoma circulating $\mathrm{M}$ antigen. Journal of Immunology, 1980, 124, 2442-2450.

De Jonge N., Kremsner P.G., Krijger F.W., Schommer G., Fillié Y.E., Kornelis D., VAn Zeyl R.J.M., Van Dam G.J., Feldmeier H. \& Deelder A.M. Detection of the schistosome circulating cathodic antigen by enzyme immunoassay using biotinylated monoclonal antibodies. Transaction of the Royal Society of Tropical Medicine and Hygiene, 1990, 84, 815-818.

De Water R., Fransen J.A. \& Deelder A.M. Ultrastructural localization of the circulating anodic antigen in the digestive tract of Schistosoma mansoni using monoclonal antibodies in an immunogold labelling procedure. American Journal of Tropical Medicine and Hygiene, 1986a, 35, 549-558.

De Water R., Fransen J.A. \& DeElder A.M. Ultrastructural localization of the circulating cathodic antigen in the digestive tract of various life-cycle stages of Schistosoma mansoni. Zeitschrift fur Parasitenkunde, 1986b, 72, 635-646.

De Water R., Van Marck E.A., Fransen J.A. \& Deelder A.M. Ultrastructural localization of the circulating anodic antigen and the circulating cathodic antigen in the liver of mice infected with Schistosoma mansoni: a sequential study. Experimental Parasitology, 1987, 64, 499-509.

Deelder A.M., Kornelis D., Van Marck E.A., Eveleigh P.C. \& VAN Egmond J.G. Schistosoma mansoni: Characterization of two circulating polysaccharide antigens and the immunological response to these antigens in mouse, hamster, and human infections. Experimental Parasitology, 1980, 50, 16-32.

Dunne D.W. \& Bickle Q.D. Identification and characterization of a polysaccharide-containing antigen from Schistosoma mansoni eggs which cross-reacts with the surface of schistosomula. Parasitology, 1987, 94, 255-268.

El-Dosoky I., VAN Marck E.A. \& DeElder A.M. Presence of Schistosoma mansoni antigens in liver, spleen and kidney of infected mice: a sequential study. Zeitschrift fur Parasitenkunde, 1984, 70, 491-497.

Hamburger J., Lustigman S., Arap Siongok T.K., Ouma J.H. \& MaHAMOUd A.A. Characterization of a purified glycoprotein from Schistosoma mansoni eggs: specificity, stability, and the involvement of carbohydrate and peptide moieties in its serologic activity. Journal of Immunology, 1982, 128, 1864-1869.

Hassanein H., Akl M., Shaker Z., el-Baz H., Sharmy R., Rabiae I. \& Botros S. Induction of hepatic egg granuloma hyporesponsiveness in murine schistosomiasis mansoni by intravenous injection of small doses of soluble egg antigen. APMIS, 1997, 105, 773-783.

Kahama I.A., Nibbeling H.A.M., van Zeyl R.J.M., Vennernald B.J., Ouma J.H. \& Deelder A.M. Detection and quantification of soluble egg antigen in urine of Schistosoma haematobium infected children from Kenya. American Journal of Tropical Medicine and Hygiene, 1998a, 59, 769-774.

KaHAma I.A. Detection of circulating soluble egg antigen (SEA) in human urinary schistosomiasis. PhD Thesis, Leiden University, 1998b. 
Koretz K., Momburg F., Otto H.F. \& Moller P. Sequential induction of MHC antigens on autochthonous cells of ileum affected by Crohn's disease. American Journal of Pathology, 1987, 129, 493-502.

VON Lichtenberg F., Bawden M.P. \& Shealey S.H. Origin of circulating antigen from the schistosome gut. An immunofluorescent study. American Journal of Tropical Medicine and Hygiene, 1974, 23, 1088-1091.

LuKaCs N.W. \& Boros D.L. Utilization of fractionated soluble egg antigens reveals selectively modulated granulomatous and lymphokine responses during murine schistosomiasis mansoni. Infection and Immunity, 1992, 60, 32093216

Nash T.E., Prescott B. \& Neva F.A. The characteristics of a circulating antigen in schistosomiasis. Journal of Immunology, 1974, 112, 1500-1507.

Nibbeling H.A.M., Kahama A.I., van Zeyl R.J.M. \& DeElder A.M. Use of monoclonal antibodies prepared against Schistosoma mansoni hatching fluid antigens for demonstration of Schistosoma haematobium circulating antigens in urine. American Journal of Tropical Medicine and Hygiene, 1998, 58, 543-550.

Nourel Din M.S., Nibbeling R., Rotmans J.P., Polderman A.M., KRIJGER F.W. \& DeElder A.M. Quantitative determination of circulating soluble egg antigen in urine and serum of Schistosoma mansoni infected individuals using a combined two-sited enzyme-linked immunosorbent assay. American Journal of Tropical Medicine and Hygiene, $1994 \mathrm{a}, 50,585-594$.

Nourel Din M.S., Kornelis D., van Zeyl R.J.M. \& Deelder A.M. Immunologic characterization of two monoclonal antibodies reactive with repetitive carbohydrate epitopes of circulating Schistosoma mansoni egg antigen. American Journal of Tropical Medicine and Hygiene, 1994b, 50, 487-498

PAN S.C.T. The fine structure of the miracidium of Schistosoma mansoni. Journal of Invertebrate Pathology, 1980, 36, 307-372.

Sharma R., Schumacher U., Adam E. Lectin histochemistry reveals the appearance of M-cells in Peyer's patches of SCID mice after syngeneic normal bone marrow transplantation. Journal of Histochemistry and Cytochemistry, 1998, 46, 143-148.

VAN MARCK E.A. Presence of the circulating polysaccharide antigen in the liver of mice infected with Schistosoma mansoni. Annales de la Société Belge de Médecine Tropicale, 1975, 55, 373-377.

VAN MARCK E.A. The glomerulopathy associated with Schistosoma mansoni infection. An experimental study in the mouse. Acta Leidensia, 1983, 50, 1-123.

Reçu le 14 janvier 2000

Accepté le 24 septembre 2000 